\title{
Chapter 5 \\ Latvian Migrants in Foreign Labour \\ Markets: Job Placement \\ and Discrimination
}

\author{
Aivars Tabuns
}

\subsection{Introduction}

As part of the free movement of labour within the EU workers have the right to accept job offers and work in any member state, resulting in increasing intra-EU mobility. The imbalance of wages and quality of life can be singled out as the main driving force behind the recent wave of East-West migration. While there is great variety between East-West migrants in terms of their motives and intentions (Luthra et al. 2014), in The Emigrant Communities of Latvia survey the majority (55\%) of respondents who emigrated after Latvia regained independence named work as the main aim of that emigration. Of those, $21 \%$ wanted to study, $16 \%$ wanted to be reunited with their family or establish their own, while $8 \%$ listed some other reason for emigration. In order to find a job, international jobseekers often turn either to specialised or general private or state employment agencies, or use their private networks. To protect the rights of jobseekers various forms of regulation have been established by the authorities in both sending and receiving countries. Despite this, some choose to enlist the help of people or agencies providing job placement illegally. Žabko et al. (2018) provides detailed characteristics and classification of job lacement intermediaries. Her analysis reveals that the avenues to employment are often complex and varied. However, there is little information on their actual impact on jobsearch outcomes for international jobseekers. Jobseekers often do not have sufficient information about job opportunities, working conditions abroad and their rights as workers (OSCE 2006), making them vulnerable to malpractice by employment agencies.

An additional cause for concern is possible exploitation by employers. The equal treatment of intra-EU migrants may be guaranteed in legal terms, yet evidence indicates subtle and more open forms of labour market discrimination. Despite previous

\footnotetext{
A. Tabuns $(\bowtie)$

Faculty of Social Sciences, University of Latvia, Riga, Latvia

e-mail: aivars.tabuns@lu.lv 
studies showing that migrants from Eastern Central Europe sometimes perform better than natives in terms of employment (Huddleston et al. 2013), there is still a significant gap with regard to employment conditions and wages, job security and quality and other work-related factors (Eurostat 2011; Pichler 2011; Spreckelsen and Kaiser 2016). In combination with social stigmatisation and 'othering' of Eastern Central European migrants (Gilmartin and Migge 2015; Luthra et al. 2014; Söhn 2013), labour market discrimination can exacerbate problems with social integration as well (Bijl and Verweij 2012; Braun and Glöckner-Rist 2012; Shubin and Dickey 2013). The situation of Eastern European migrants in the labour market has been the focus of several studies (Gilmartin and Migge 2015; Johns 2013; Söhn 2013; Spreckelsen and Seeleib-Kaiser 2016), yet information is often incomplete, too general or lacking the perspective of migrants themselves.

This chapter focuses on the vulnerable position of Latvian workers in the labour markets of their destination countries, especially their exploitation by job placement intermediaries and the discrimination they face.

Following an overview of job placement agents and regulations, the process by which Latvian jobseekers find work abroad will be analysed, and, in particular, the role that service providers play in that process. The article considers the situation of Latvian migrant workers abroad and how that is linked with the use of certain types of intermediaries. Importantly, the chapter offers deep insight into how the migrants themselves experience their situation in workplaces abroad.

The chapter builds on data from The Emigrant Communities of Latvia survey, taking advantage of both quantitative and qualitative data (see Mierina in this volume), as well as insights from previous surveys on the subject. The questionnaire used in the survey included questions about the way respondents found their first job and their experience of working with employment providers, as well as six different questions charting workplace discrimination (see Table 5.3).

\subsection{Employment Service Providers and Regulations Protecting Workers}

While analysing commodity prices and wages 250 years ago, Adam Smith concluded that 'A man is, of all sorts of luggage, the most difficult to be transported' (Smith 1776). Today the situation has changed, as illustrated by the intensification of migration processes. Nowadays it is easier for people to change their place of residence and thus find new job opportunities, while the organisation of labour migration is increasingly becoming a type of business. As employers are often unwilling to invest time and effort in the search for workers, they use an intermediary company that searches for the right personnel and ensures an adequate assessment of the motivation and operability of potential employees (Findlay et al. 2013). If, during the great emigration periods of previous centuries, these services were not supervised or regulated by the state, or selective constraints were applied by the state 
to immigration rather than emigration, labour market regulation nowadays includes measures for both emigration and immigration, and an increasing amount of attention is paid by states to the protection of jobseekers' rights (Summerville 2004).

The European Union (EU) regulates not only the free movement of goods, services and capital, but also the free movement of the labour force. Workers have the right to accept job offers and move freely within the territory of the EU, to reside in any member state for employment and to stay in its territory after the completion of employment. At the same time, there is far less regulation relating to job placement services to other countries.

Many international organisations, such as the Organisation for Security and Co-operation in Europe (OSCE), the International Organisation for Migration (IOM) and the United Nations' agency for labour issues, the International Labour Organisation (ILO) have been focusing on the activities of private employment agencies.

The regulations of private employment agencies are based on the International Labour Organisation's (ILO) Convention (ILO 1997), which came into force in the year 2000 and has been ratified by 30 countries, including Lithuania (2004). However, Latvia and Estonia have not ratified the Convention. In 1997, the ILO also developed recommendations for the adoption of the Convention (ILO 1997). It continued to conduct regular surveys in this sector, and in 2007 developed a guide to regulating, monitoring and running private employment agencies (PrEA) (ILO 2007). Among other things, the document proposes self-regulatory tools for employment service providers, including professional codes of conduct and guidelines for co-operation between private agencies and public employment services.

One of the most important documents dealing with job placement abroad is the Handbook on Establishing Effective Labour Migration Policies in Countries of Origin and Destination (OSCE 2006). One of the chapters of the handbook analyses the policies of 'sending' countries, which are aimed at protecting emigrants. This document defines the national policy strategies, including the need for rigorous and regular monitoring of licensing and performance of private employment agencies, the co-operation of state institutions with the host countries of emigrants and the information and educational tools available to migrants - while simultaneously focusing on the speed and scale of the 'brain-drain'. Another guide (Directorate General for Internal Policies 2013) aims to develop recommendations to help private employment agencies comply with international human rights standards. The trends and challenges of migration are systematically analysed by the Organisation for Economic Co-operation and Development (OECD).

Emigrant protection issues are monitored by the International Organisation for Migration (IOM). The organisation collects information on various national policies and provides potential emigrants with the necessary knowledge of working conditions in the new countries of residence. For instance, the project HEADSTART: Fostering Integration before Departure includes several EU countries (Austria, the Czech Republic, Germany, Hungary, Italy, the Netherlands, Portugal and Slovakia) and has developed a manual for training centre workers that helps to prepare emigrants for living and working abroad (Pillinger 2015). 
Although the employment service providers are mentioned in many policy documents, just a few detailed studies are devoted to this topic. The activity of private employment agencies is analysed in detail in a 2013 European Parliament study (European Commission 2013). It deals with documents regulating recruitment agencies both at the supra-national level (ILO, GATS, EU) and national level (Great Britain, Germany, Denmark, Belgium, Italy and Poland), showing that approaches differ to the regulation and supervision of private employment agencies in various countries (Pijpers 2010; van Liemt 2013).

In a 3-year study of the migrant recruitment strategies of the UK's private recruitment agencies between 2005 and 2008, Chris Forde and Robert MacKenzie interviewed both service providers and recipients (Forde and MacKenzie 2010) and identified three employment strategies.

The first was classified as a business case, and focused solely on the fulfilment of the needs of employers. The second approach was labelled as 'minimal compliance' or the 'penalty avoidance' approach. Here, agencies complied with the requirements of the employers, the health and safety of the workforce and the regulatory requirements of labour law. The third approach was labelled the 'social justice approach' - companies following this strategy intended to represent the needs of emigrants in full (MacKenzie and Forde 2008).

An extended list of the most common violations by recruitment agencies was presented in the legislative initiatives' submission in the House of Commons by the British Member of Parliament Andrew Miller (Keter 2007). The document indicated that employment relationships were often unfairly terminated and that immigrants and migrants were often exposed to psychological intimidation and other forms of violence, such as bullying and harassment.

An extensive list of typical violations at the workplace by employers has been compiled by British trade unions (Anderson et al. 2007; Clark 2004; Migrant Workers Agency 2007), including lower salaries than were originally promised, unfair wage deductions or penalties, paying overtime at the rate of basic hours, jobs without a signed contract and breaks that were shorter than specified.

In Latvia, according to State Employment Agency (NVA 2015) data, 108 companies had employment service licenses on 14 April 2015, and about half of the companies registered in Latvia had a license for work placement abroad, including 39 in Germany, 20 in Britain, 10 in Norway, 10 in the Netherlands, 8 in Ireland and 5 in Russia. Employment opportunities were offered to jobseekers in other countries as well, but by a significantly smaller number of companies.

However, a multi-faceted study conducted between 2014 and 2015 by the Baltic Institute of Social Sciences (BISS) in collaboration with the University of Oslo Regional Studies Institute reveals that, despite the substantial number of licenses issued by the State Employment Agency, the Latvian work placement companies are weak in Norway. It is most common for Latvians to search for a job through personal contacts, as they have low levels of trust in advertisements and job placement intermediaries (Žabko 2015).

The State Employment Agency (SEA) and the Consumer Rights Protection Centre (CRPC) ensures oversight of these companies. In 2010, the SEA and the 
CRPC conducted a survey in which they detected violations in the activities of several work placement service providers, and applied administrative sanctions to the businesses for unfair commercial practices (NVA, PTAC 2010). After the CRPC evaluated the commercial practices of several work placement providers, it banned a number of companies from providing information about their offers and withdrew the licenses of six businesses. The authors of the aforementioned study (Žabko 2015) indicate that consumers were often provided with a misleading impression that the company could legitimately provide services, when in fact it did not have a license to do that.

The Latvian media often reports on rogue service providers which do not fulfil their agreements with jobseekers. Warnings and recommendations are regularly published on how to avoid dishonest service providers. However, information about Latvian employment providers and the quality of their services is unsystematic, and qualitative methods are most frequently used in sociological surveys on the subject.

Frequently detected fraud methods listed by the SEA (NVA 2015) include:

- The jobseeker does not receive a contract of work placement services;

- They are not informed about training fees or that they will have to repay training expenses on leaving;

- They are offered a different, lower paid job or their work has been terminated;

- They are offered another, lower paid job or are refused work;

- They are offered lower standard or more expensive housing conditions;

- They are presented with additional working conditions;

- They are faced with an unjustified claim that they 'owe' their employer money and this debt is deducted from their salary;

- Employment service providers do not respond to the jobseeker's complaints.

Jobseekers experiencing difficulties with employment contacts can report violations of the license to the SEA.

\subsection{Migrants' Experiences with Employment Service Providers}

The analysis of job seeking experiences is based on the answers of those respondents (in total 6171 respondents) who indicated that their main goal of emigration was to work abroad and who answered the question relating to how they found their first job abroad. In the analysis of the treatment of workers at their workplace, only those who emigrated after 1991 i.e., after Latvia regained independence, were included - regardless of how they found that job.

The results show that almost half of the respondents found their first paid job in the host country with the help of relatives or friends (45\%) (Fig. 5.1). The second most common way of finding work was by applying for competitions or advertisements (20\%). The third method, of using the services of employment agencies or intermedi- 


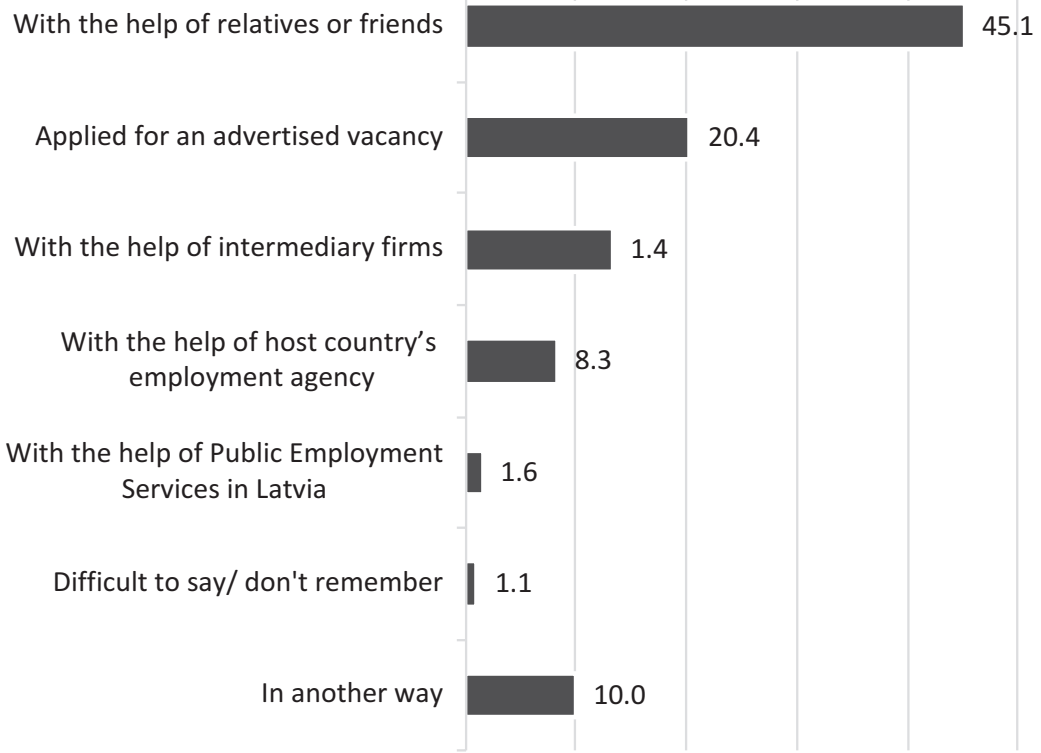

Fig. 5.1 How did the respondent find a job abroad? (\%) (Source: The author, based on The Emigrant Communities of Latvia survey)

aries, accounted for $13 \%$ of jobseekers while the rest were helped by employment agencies in the host countries $(8.3 \%)$ or found work in another way $(10 \%)$.

The paid services of intermediaries were used more often by respondents living in small towns or in the countryside, but less often by those living in Riga (15\% and $10 \%$ respectively). They were equally popular among men and women, as well as people of different ages and levels of education. However, the data shows that the services of intermediary firms were used most often by those who emigrated between 2000 and 2003 (22\%) and has been decreasing since, falling to $11 \%$ among those who emigrated in 2011 or later.

It is important to point out that in various countries the proportions between the first three ways of finding work differed considerably (see Table 5.1). Moreover, the use of intermediary services differed quite significantly in different emigration waves.

The survey also focused on the type of employment intermediaries and how successfully they operated. Among respondents whose main aim of leaving was to work abroad and who used paid intermediaries, $37 \%$ tried to find a job with the help of the potential host country's employment firms (HCEF) while $33 \%$ used the services of Latvia's employment firms (LVEF). Around 20\% of respondents used individual intermediaries and 5\% went to unlicensed intermediary groups (Fig. 5.2).

The services of licensed employment companies in Latvia (LVEF) were used mostly by Latvian emigrants living in Ireland, Norway and Cyprus, while those in 
Table 5.1 Way of finding the first job for respondents from different countries (\%)

\begin{tabular}{l|l|l|c}
\hline State & $\begin{array}{l}\text { Applied for competitions or } \\
\text { advertisements }\end{array}$ & $\begin{array}{l}\text { With the help of } \\
\text { relatives or friends }\end{array}$ & $\begin{array}{l}\text { With the help of } \\
\text { intermediary firms }\end{array}$ \\
\hline USA & 23.6 & 40.2 & 12.5 \\
\hline Austria & 31.8 & 44.5 & 11.9 \\
\hline Belgium & 35.3 & 41.7 & 6.3 \\
\hline Denmark & 12.5 & 58.5 & 11.4 \\
\hline Ireland & 18.8 & 60.6 & 9.5 \\
\hline UK & 14.2 & 44.2 & 18.4 \\
\hline The Netherlands & 15.4 & 43.2 & 23.4 \\
\hline Norway & 16.6 & 58.6 & 11.3 \\
\hline Finland & 19.7 & 41.2 & 9.1 \\
\hline Germany & 20.6 & 51.2 & 9.2 \\
\hline Sweden & 21.1 & 52.2 & 6.8 \\
\hline
\end{tabular}

Source: The author, based on The Emigrant Communities of Latvia survey

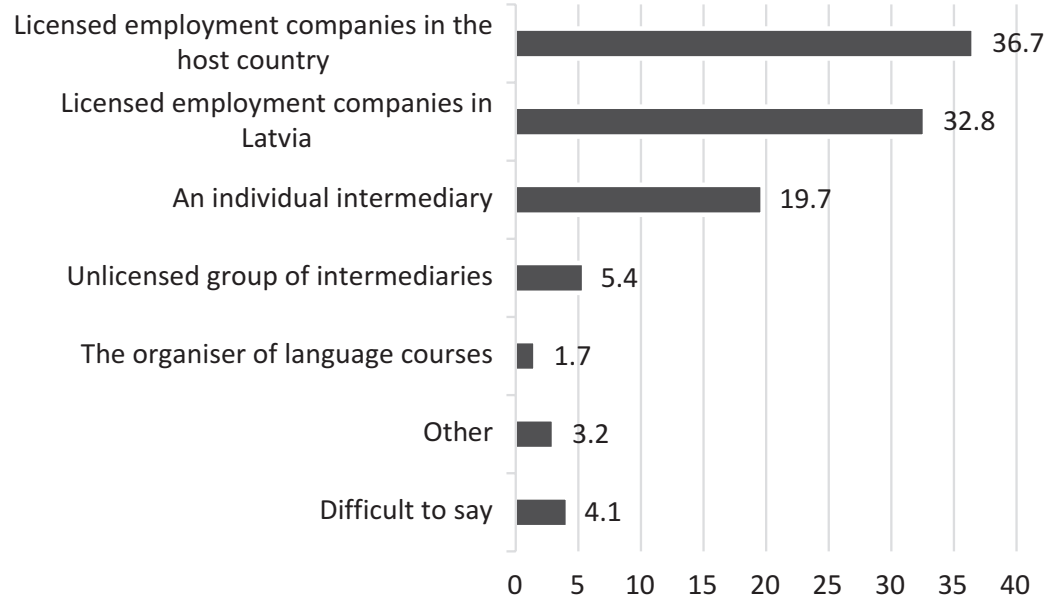

Fig. 5.2 The type of paid job placement services used (\%) (Source: The author, based on The Emigrant Communities of Latvia survey)

Denmark, Sweden, Belgium and the Netherlands used the services of the host country. Latvian migrants in Italy and France engaged individual intermediaries.

The survey data indicates that the host country's recruitment company (HCEF) services were chosen comparatively more often by those from cities, but those living in the countryside at the time used the services of Latvian companies (LVEF). HCEF services were chosen more often by younger respondents (15-24 years), and - interestingly enough - by managers and unskilled workers alike. Older people and Russians more often chose to use individual intermediaries while unskilled workers used the services of unregistered intermediary firms. 
When answering survey questions evaluating the services of firms or intermediaries, more than two thirds (72\%) of respondents who had used these services chose the answer 'firms or intermediaries fully fulfilled their obligations'. Eleven percent of respondents indicated that the work differed substantially from what was promised; 3\% thought they were not offered anything acceptable and $7 \%$ believed it was a fraud. Several respondents indicated they did not have a contract on departure as they had relied on mutual agreements.

When asked which contract clauses were not fulfilled or only partly fulfilled, the respondents most often indicated non-compliance on job conditions (58\%), working hours or work schedule (47\%) and payment (42\%). Less frequently, respondents mentioned inadequate living conditions $(32 \%)$, inadequate social security or protection and high rents for housing (26\%). Several respondents pointed out that quite soon after arrival they refused the intermediary services because they were offered a completely different job, not the job that was initially promised.

A common experience among migrant workers was that promises were broken. Among situations mentioned by respondents were that the work promised was not there, contracts were not fulfilled or there was no work at all. Specific complaints included:

- We ended up in another city and at another factory;

- I found myself on the street;

- We were dropped off [e.g., in Northampton Park] and abandoned there;

- Although the agreement was for 3 months, after just 2 weeks the direct employer ended the job;

- We were charged more than was initially quoted for work permits and travel expenses;

- After the contract finished we were not paid the money we were owed; i.e. we were 'ripped off'.

Similar examples were mentioned in The Emigrant Communities of Latvia qualitative interviews. Intermediary companies were frequently described as fraudsters by jobseekers, especially those over 55 and those living in the capital city.

Respondent from the UK who left Latvia in 2011 shared:

My husband flew to London through one Riga firm. As with many of our countrymen, he was promised a job in a restaurant as a cook's assistant. When he went there, of course, that firm says they have no jobs.

Jobseekers who replied to advertisements online were also often cheated as this respondent who left Latvia for Germany in 2009:

We saw an advert asking for two gardeners, cleaners and a yardman. Now I understand I was naive but the contact was a Latvian so we contacted him. Everything seemed fine at first but it turned out differently. When I got out of the bus at the [airport] terminal, I was called and told to wait. And I'm still waiting! I haven't heard anything from that man. Two more men were with me. They turned around and went back to Latvia by bus that evening. 
Of those jobseekers who used employment agencies in Latvia, 73\% found a job abroad while $56 \%$ of potential migrants using agencies in the host country found work. Half the respondents who used individual intermediaries secured a job abroad, while only $33 \%$ of respondents using unlicensed firms were successful in finding employment. Overall about $60 \%$ of respondents using intermediaries found work abroad.

\subsection{Treatment of Migrant Workers in the Workplace}

The results of The Emigrant Communities of Latvia survey show that 35\% of Latvian migrant workers encountered some form of discrimination or unfair treatment in their workplace. The most common form of unfair treatment mentioned by $18 \%$ of respondents was that they were paid less than workers from the host nation for similar work. Such a situation was most widespread in Germany and Nordic countries. Here, 29\% of Latvian workers made this complaint (Table 5.2).

Being given unpleasant and/or unprofitable tasks more frequently than host nation colleagues was mentioned by $14 \%$ of Latvian migrants, who also complained they experienced more difficulty negotiating suitable work schedules and shift patterns. These issues were mentioned most by Latvian workers in Germany and Southern Europe. Twelve percent said they were expected to meet tougher requirements with respect to work discipline or productivity than host nation colleagues: most often those working in Eastern Europe, the UK and Ireland. One can conclude that both the frequency and character of discrimination varied from country to country.

At the time of the survey most Latvian workers abroad (85\%) had a permanent contract with their employer. Of those who did not, $8 \%$ had a verbal agreement while $4 \%$ did not have a direct agreement with the employer, but a written contract with a temporary work agency (Fig. 5.3). Verbal agreements were most common in the construction industry (22\% of migrant construction workers had verbal agreements), while contracts with temporary work agencies were most common in manufacturing (9\% of migrant workers in this field had such contracts).

Regarding national insurance or social security payments $9 \%$ of the Latvian migrant workers knew that the employer did not make them on their behalf, while $8 \%$ were not sure these payments were made. Employers in the construction sector were most likely not to make social security payments, according to the respondents. Almost one in five (19\%) said they felt contributions were not made, $7 \%$ were not sure. Those working in IT also felt the same way: $11 \%$ knew that social security contributions were not made while $7 \%$ were not sure. 


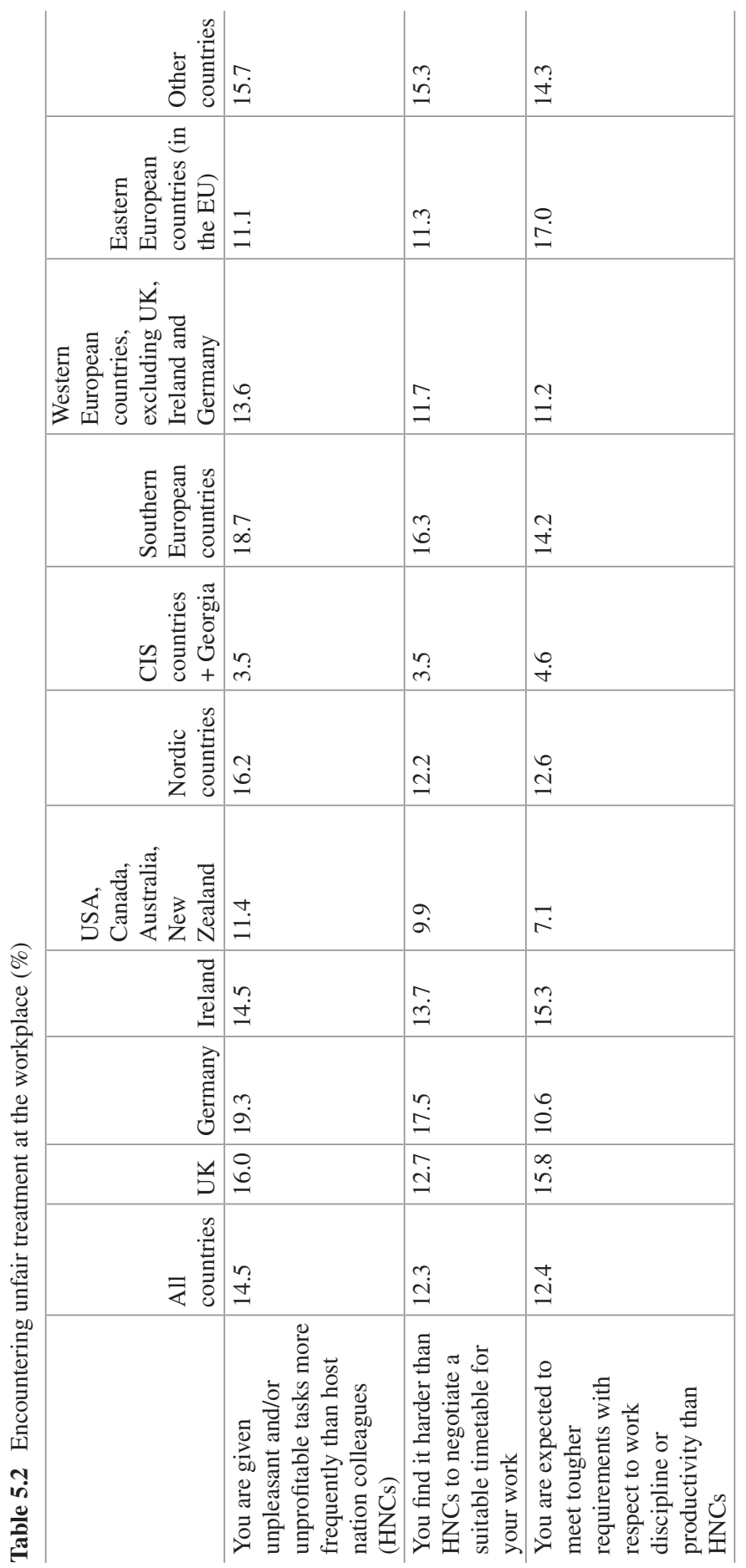




\begin{tabular}{|c|c|c|}
\hline$\ddot{n}$ & $\stackrel{\sim}{\dot{I}}$ & $\stackrel{+}{\dot{r}}$ \\
\hline$\stackrel{ナ}{\circ}$ & $\stackrel{9}{=}$ & $\ddot{6}$ \\
\hline$\stackrel{\infty}{\infty}$ & $\stackrel{0}{0}$ & $\stackrel{i}{\mathrm{I}}$ \\
\hline$\underset{\infty}{\circ}$ & $\dddot{n}$ & $\vec{n}$ \\
\hline$\underset{\text { in. }}{\stackrel{0}{ }}$ & $\stackrel{m}{q}$ & กֶ. \\
\hline$\stackrel{\nabla}{\Delta}$ & $\begin{array}{l}0 \\
\infty \\
\infty\end{array}$ & $\vec{m}$ \\
\hline$\dot{m}$ & $\begin{array}{l}\stackrel{0}{\mathscr{n}} \\
\underline{-}\end{array}$ & ma \\
\hline$\stackrel{9}{\check{2}}$ & $\stackrel{\infty}{\stackrel{\varrho}{2}}$ & $\stackrel{n}{2}$ \\
\hline 导 & $\begin{array}{l}\hat{\sigma} \\
\infty \\
\infty\end{array}$ & $\stackrel{0}{\circ}$ \\
\hline$\exists$ & $\stackrel{n}{ \pm}$ & $\stackrel{i}{\stackrel{i}{I}}$ \\
\hline$\stackrel{t}{\circ}$ & $\stackrel{\infty}{\stackrel{\infty}{\check{I}}}$ & $\stackrel{0}{0}$ \\
\hline 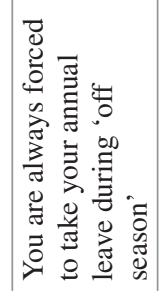 & 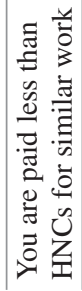 & 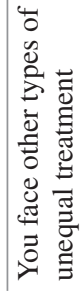 \\
\hline
\end{tabular}




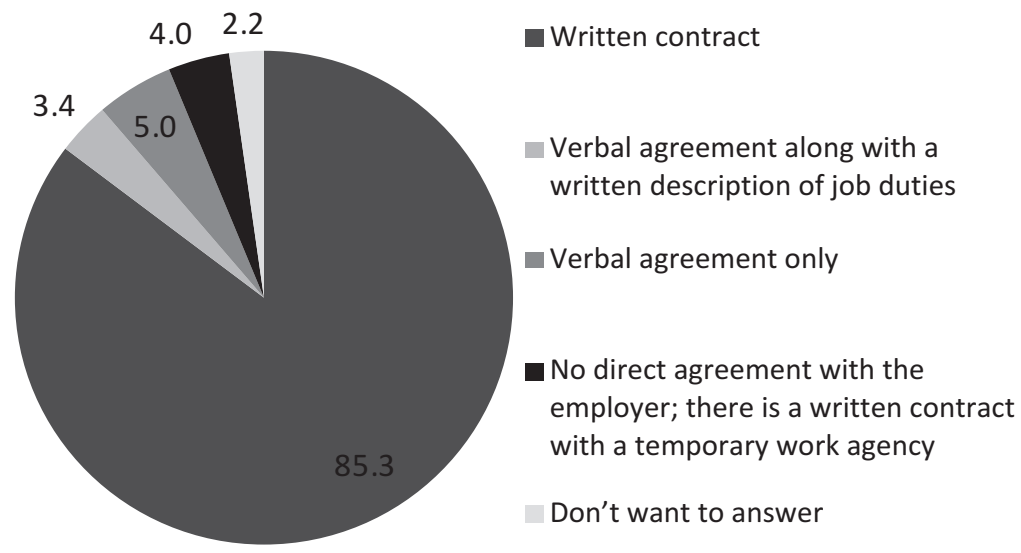

Fig. 5.3 Type of contract at workplace (\%) (Source: The author, based on The Emigrant Communities of Latvia survey)

\subsection{Discrimination Against Latvian Migrant Workers Abroad}

In order to summarise the information about how widespread cases of discrimination were for the Latvian diaspora, an index of discrimination was calculated on a scale from 0 to 5, where 0 means the respondent has not encountered any form of unfair treatment and 5 means they have encountered all measured forms of unfair treatment.

As can be seen in Table 5.3., Latvian workers were most likely to face unfair treatment in the UAE, the Netherlands, Denmark, Greece, Finland and Germany. Such cases were also relatively common in Ireland, Sweden, Switzerland, Iceland and Lithuania. The data showed that Nordic and Western European countries had the highest scores of unfair treatment reported by migrants themselves.

The analysis of demographic groups revealed that the Latvian migrants more likely to face discrimination at work were those who had lived abroad for less than 2 years, who lived in towns or rural areas rather than the capital city; were skilled and unskilled workers as opposed to managers and professionals and were either young people under 24 years of age or those above 65 (Fig. 5.4).

Overall, the index of discrimination was highest in agriculture, forestry or fisheries, manufacturing or energy, construction, transport or storage services (Table 5.4). Those in sales, catering or the hospitality sectors faced less frequent discrimination. It is important to note that unfair treatment was most often encountered in those companies abroad that were registered in Latvia. One can conclude that these companies were trying to increase their competitiveness by attracting a cheaper workforce from Latvia. This conclusion is in line with previous findings (Mierina 2016) 
Table 5.3 Encountering unfair treatment at the work place in various countries

\begin{tabular}{l|l|l|l|l|l}
\hline & $\begin{array}{c}\text { Index of } \\
\text { discrimination }\end{array}$ & $\begin{array}{l}\text { Number of } \\
\text { respondents } \\
\text { (unweighted) }\end{array}$ & & $\begin{array}{c}\text { Index of } \\
\text { discrimination }\end{array}$ & $\begin{array}{l}\text { Number of } \\
\text { respondents } \\
\text { (unweighted) }\end{array}$ \\
\hline UK & .77 & 4952 & Estonia & .29 & 107 \\
\hline Germany & .97 & 1475 & Iceland & .91 & 92 \\
\hline Ireland & .91 & 1223 & Cyprus & .71 & 76 \\
\hline Norway & .87 & 838 & Luxembourg & .20 & 70 \\
\hline USA & .50 & 802 & Lithuania & .94 & 60 \\
\hline Sweden & .90 & 569 & Greece & 1.19 & 58 \\
\hline Denmark & 1.17 & 471 & $\begin{array}{l}\text { Czech } \\
\text { Republic }\end{array}$ & .40 & 52 \\
\hline The & 1.28 & 399 & UAE & 1.53 & 48 \\
\hline Netherlands & .28 & 370 & Turkey & .51 & 42 \\
\hline Russia & .46 & 270 & Ukraine & .33 & 41 \\
\hline Belgium & .35 & 233 & Portugal & .56 & 40 \\
\hline Canada & 1.12 & 225 & Belarus & .08 & 39 \\
\hline Finland & .42 & 208 & Israel & .78 & 36 \\
\hline France & .58 & 203 & Poland & .62 & 34 \\
\hline Austria & .46 & 172 & China & .00 & 34 \\
\hline Spain & .71 & 161 & China & .15 & 28 \\
\hline Italy & .49 & $\begin{array}{l}\text { New } \\
\text { Zealand }\end{array}$ & .23 & 26 \\
\hline Australia & & Malta & .17 & 22 \\
\hline Switzerland & .91 & 133 & & & \\
\hline Discriminat & & & & & \\
\hline
\end{tabular}

Discrimination index on a scale from 0 to 5

Source: The author, based on The Emigrant Communities of Latvia survey

that diaspora workers evaluate the attitude of employers abroad as being better than employers in Latvia. Cases of discrimination were more common among those with only a verbal agreement or a temporary contract with an employment agency. Moreover, they were more common in situations when the worker had only a shortterm contract, temporary contract or a contract for completing a specific task (up to 1 year).

If we look at discrimination scores depending on the use of the services of job placement intermediaries, one can conclude that those who did use such services have, on average, been subject to more situations of discrimination at the workplace (Sig. $<0.001$ ), particularly those who used the services of unlicensed groups of intermediaries (Fig. 5.5). Reducing the use of such services can be expected to have a positive impact on the labour market situation of migrants in general.

Finally, the process of having experienced discrimination can affect migrants' identification with the host country's inhabitants as well as their plans to return to Latvia (Sig.<0.001) (Table 5.5). 


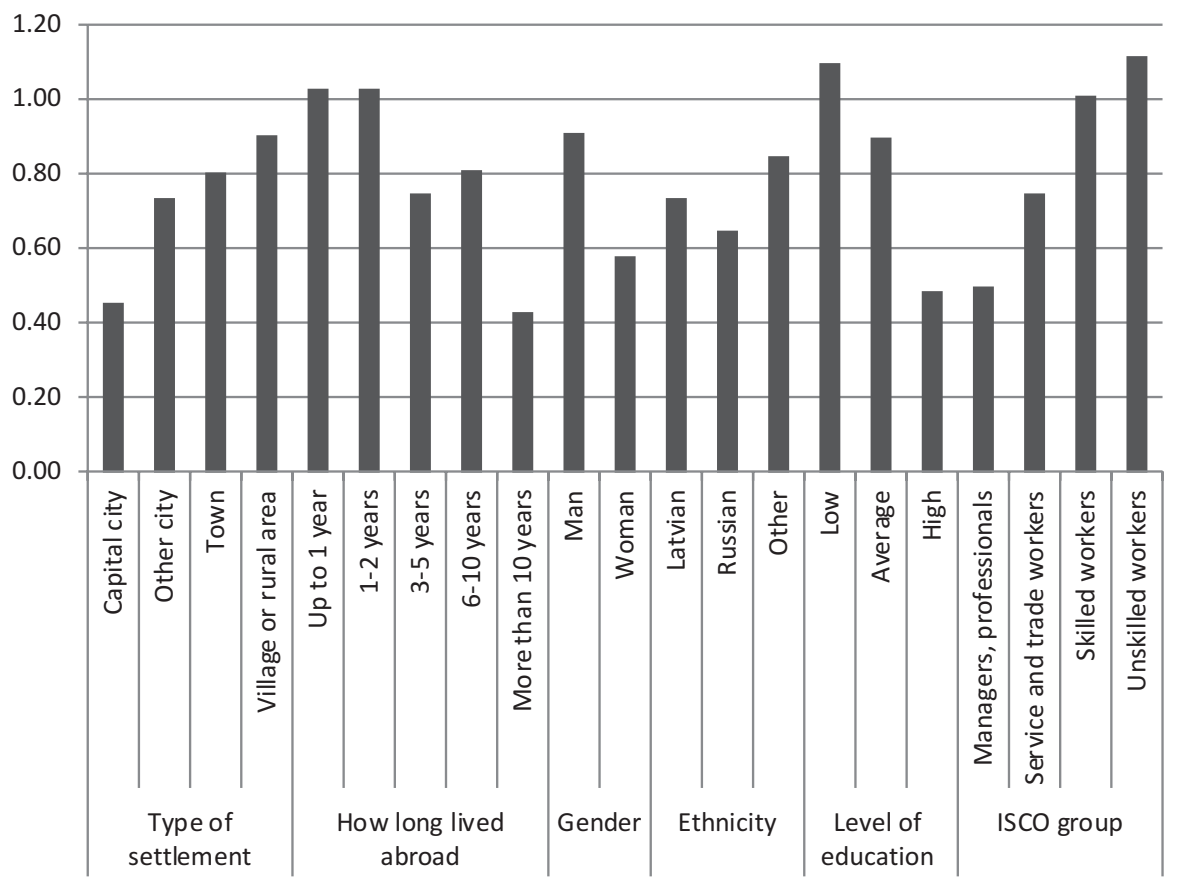

Fig. 5.4 Experience of discrimination in various demographic groups (\%) (Source: The author, based on The Emigrant Communities of Latvia survey. Note: Discrimination index on a scale from 0 to 5 )

\subsection{Conclusions}

While various national and international employment policy documents have been developed with the aim of protecting the rights of mobile citizens in the EU, emigrants continue to encounter violations of their labour rights. They are often poorly informed about their rights and the specifics of the types of contracts with employment agencies and employers abroad. The analysis shows that emigrants from different countries face similar problems. Co-operation between national authorities should thus be promoted.

The data collected as part of The Emigrant Communities of Latvia project showed that almost a fifth of migrant workers who used the services of intermediary job placement firms had experienced unfair treatment at the hands of these service providers. Although the respondents who emigrated after 2011 indicated such cases less frequently, the fact that $11 \%$ of emigrants in the last wave (2011+) of emigration claimed that 'the work differed substantially from the job promised' and 7\% thought that 'it was a fraud' means the national authorities do not control the employment activities of firms and the quality of the services provided sufficiently or carefully enough. 
Table 5.4 Experience of discrimination depending on the sector of employment and the type of contract $(\%)$

\begin{tabular}{|c|c|c|}
\hline \multirow{12}{*}{$\begin{array}{l}\text { Sector of } \\
\text { employment }\end{array}$} & Agriculture, forestry or fisheries & 1.04 \\
\hline & Manufacturing or energy & .93 \\
\hline & Construction & 1.02 \\
\hline & Sales, catering or hospitality & .75 \\
\hline & Transport or storage & .97 \\
\hline & Information and communication services & .47 \\
\hline & Services in finance, insurance, research, administration or real estate & .48 \\
\hline & Government and national defence; national insurance/social security & .22 \\
\hline & Education & .40 \\
\hline & Healthcare and social services & .52 \\
\hline & Other & .65 \\
\hline & Difficult to say & .56 \\
\hline \multirow[t]{6}{*}{ Type of company } & A company registered in Latvia & 1.38 \\
\hline & A company registered in another country & .74 \\
\hline & $\begin{array}{l}\text { A government/municipal institution or a non-profit organisation in the } \\
\text { country of residence }\end{array}$ & .63 \\
\hline & $\begin{array}{l}\text { A government/municipal institution or a non-profit organisation of } \\
\text { Latvia }\end{array}$ & .27 \\
\hline & An international organisation & .58 \\
\hline & Difficult to say & .91 \\
\hline \multirow[t]{5}{*}{ Type of contract } & Written contract & .67 \\
\hline & Verbal agreement along with a written description of job duties & .70 \\
\hline & Verbal agreement only & 1.34 \\
\hline & $\begin{array}{l}\text { No direct agreement with the employer; a written contract with a } \\
\text { temporary work agency }\end{array}$ & 1.43 \\
\hline & Don't want to answer & .69 \\
\hline \multirow[t]{5}{*}{ Length of contract } & Permanent (no fixed end date) & .67 \\
\hline & Currently in a probation period & .81 \\
\hline & $\begin{array}{l}\text { Temporary or fixed-term, or for the performance of a particular task } \\
\text { or tasks (for less than a year) }\end{array}$ & 1.28 \\
\hline & $\begin{array}{l}\text { Temporary or fixed-term, or for the performance of a particular task } \\
\text { or tasks (for more than } 1 \text { year) }\end{array}$ & .55 \\
\hline & Don't want to answer & .73 \\
\hline
\end{tabular}

Source: The author, based on The Emigrant Communities of Latvia survey

Discrimination index on a scale from 0 to 5

One safeguard could be the introduction of standardised contracts, to be developed and implemented by these agencies. Such a contract would define the rights and responsibilities of both agencies and employees, as well as identifying ways of solving disagreements and sanctioning procedures. Contract registration procedures and control procedures should be agreed and set in law, with the understanding that failure to conclude such an agreement would serve as a basis for revoking the agency's license. 


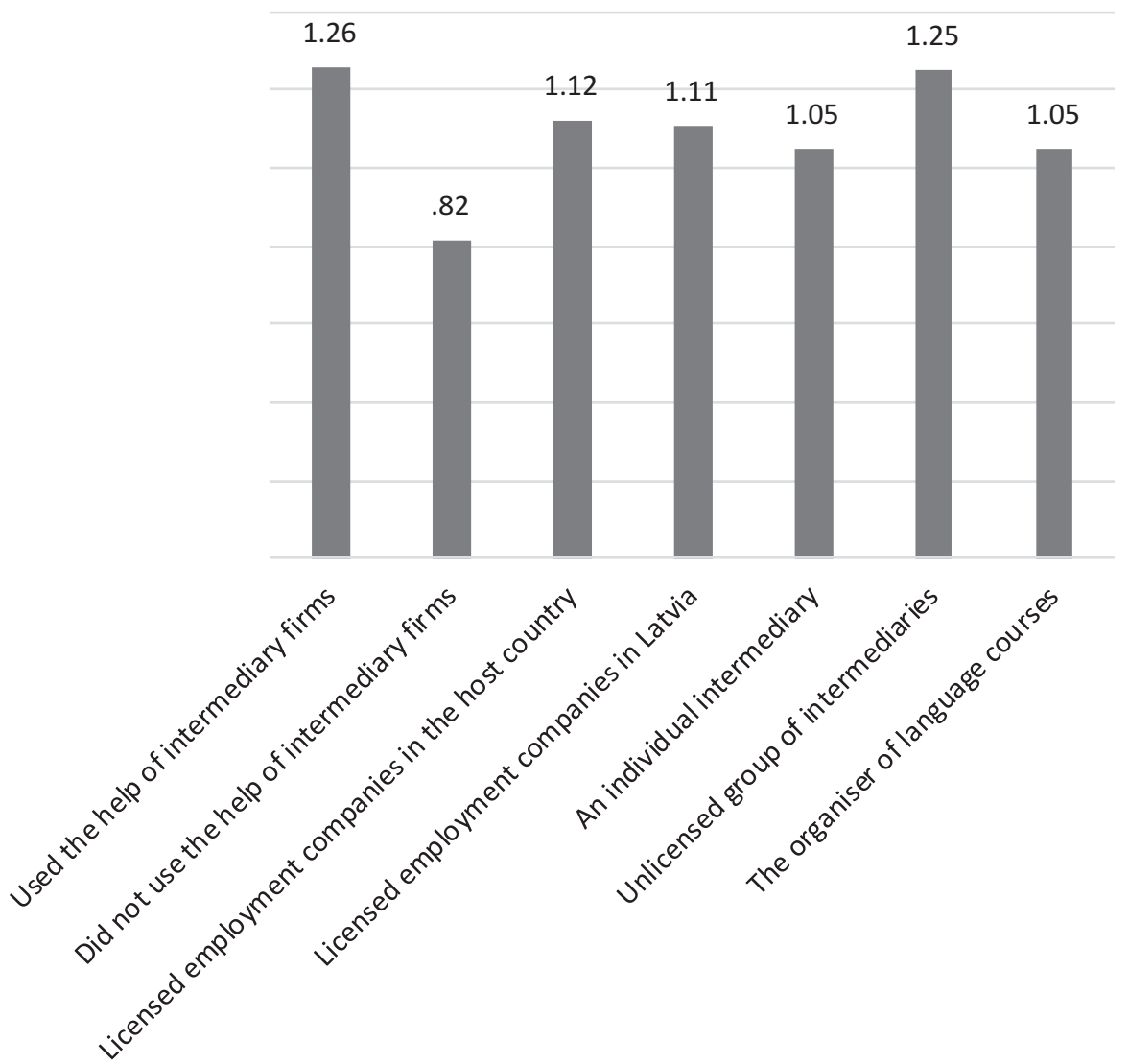

Fig. 5.5 Discrimination depending on the type of paid job placement services used (Source: The author, based on The Emigrant Communities of Latvia survey. Note: Discrimination index on a scale from 0 to 5 )

According to The Emigrant Communities of Latvia survey, 15\% of Latvian migrant workers did not have a written employment contract with the employer at the time it was conducted, and for $17 \%$ of them the employer did not or probably did not make social security contributions. One can conclude that around one in six Latvian workers in the migrant labour market are in a precarious and vulnerable position. Thirty-five percent have encountered unequal, discriminatory attitude at their workplace. Interestingly, Nordic and Western European countries had the highest scores of discrimination reported by migrants themselves, probably attesting to the subjective nature of feeling that they were treated unfairly compared to their host nation colleagues. Discrimination hinders migrants' identification with the host country's inhabitants and fuels their willingness to return home.

The results of this study suggest that in order to reduce discrimination in the workplace, it is important to reduce the shadow economy and to improve the information available to migrant workers about their rights. Particular focus should be 
Table 5.5 Return migration plans, identification with the inhabitants of the host country, and experience with discrimination $(\%)$

\begin{tabular}{l|l|l}
\hline & & $\begin{array}{l}\text { Discrimination } \\
\text { score }\end{array}$ \\
\hline \multirow{2}{*}{$\begin{array}{l}\text { Plans to move back to Latvia } \\
\text { permanently within the next 6 months }\end{array}$} & Plans to return & 1.17 \\
\cline { 2 - 3 } & Depends on circumstances & 0.86 \\
\cline { 2 - 3 } & Does not plan to return & 0.52 \\
\hline \multirow{2}{*}{$\begin{array}{l}\text { Identification with people living in the } \\
\text { host country }\end{array}$} & I feel strongly that I belong & 0.3 \\
\cline { 2 - 3 } & I tend to feel that I belong & 0.4 \\
\cline { 2 - 3 } & $\begin{array}{l}\text { I neither feel I belong nor do I } \\
\text { feel I do not belong }\end{array}$ & 0.8 \\
\cline { 2 - 3 } & I tend to feel that I do not belong & 0.9 \\
\cline { 2 - 3 } & $\begin{array}{l}\text { I feel strongly that I do not } \\
\text { belong }\end{array}$ & 1.6 \\
\hline
\end{tabular}

Source: The author, based on The Emigrant Communities of Latvia survey

Discrimination index on a scale from 0 to 5

given to illegal service providers and work on temporary contracts or contracts with an employment agency, especially highlighting the situation in certain problematic employment sectors.

For future studies, it would be productive to gather information about contract enforcement by new employers, about additional requirements, deductions and requests for involuntary overtime. It would be useful to conduct analysis of complaints received by the CRPC and SEA on dishonest intermediaries, to investigate unlicensed employment service providers and to inform job seekers about possible fraudulent practices so that the rights of migrant workers can be better protected.

\section{References}

Anderson, B., Clark, N., Parutis, V. (2007). New EU members? Migrant workers' challenges and opportunities to UK trades unions: A Polish and Lithuanian case study, COMPAS Report for the Trades Union Congress. https://www.compas.ox.ac.uk/2008/pr-2008-trades_unions_polish_lithuanian-2/. Accessed 28 Nov 2018.

Bijl, R., \& Verweij, A. (2012). Measuring and monitoring immigrant integration in Europe integration policies and monitoring efforts in 17 European countries. The Hague: The Netherlands Institute for Social Research.

Braun, M., \& Glöckner-Rist, A. (2012). Patterns of social integration of Western European Migrants. Journal of International Migration and Integration, 13(4), 403-422.

Clark, N. (2004). Propping up rural and small-town Britain: migrant workers from the new Europe, TUC. https://www.tuc.org.uk/international-issues/migration/migrant-workers-arepropping-rural-and-small-town-britain. Accessed 27 Mar 2016.

Directorate General for Internal Policies. (2013). The role and activities of employment agencies. Brussels: European Parliament. http://www.europarl.europa.eu/RegData/etudes/etudes/ join/2013/507459/IPOL-EMPL_ET\%282013\%29507459_EN.pdf. Accessed 27 Mar 2016.

European Commission. (2013). Employment and recruitment agencies. Sector Guide on implementing the UN guiding principles on business and human rights. Brussels: European 
Commission. http://ec.europa.eu/enterprise/policies/sustainable-business/files/csr-sme/csrera-hr-business_en.pdf. Accessed 27 Mar 2016.

Eurostat. (2011). Indicators of immigrant integration. A pilot study. Brussels: EUROSTAT / European Commission.

Financenet. (2010). Brīdina darba meklētājus par negodīgiem pakalpojumu sniedzējiem [Jobs seekers warned about fraudulent employment services]. http://financenet.tvnet.lv/zinas/342649Bridina_darba_mekletajus_par_negodigiem_pakalpojumu_sniedzejiem. Accessed 2 Apr 2016.

Findlay, A., McCollum, D., Shubin, S., Apsite, E., \& Krisjane, Z. (2013). The role of recruitment agencies in imagining and producing the 'good' migrant. Social \& Cultural Geography, 14(2), $145-167$.

Forde, C., \& MacKenzie, R. (2010). The ethical agendas of employment agencies towards migrant workers in the UK. Journal of Business Ethics, 97(1), 31-41.

Gilmartin, M., \& Migge, B. (2015). European migrants in Ireland: Pathways to integration. European Urban and Regional Studies, 22(3), 285-299.

Huddleston, T., Niessen, J., \& Tjaden, J. D. (2013). Using EU indicators of immigrant integration. Brussels: European Commission.

ILO. (1997). Private employment agencies convention (No. 181). http://www.ilo.org/dyn/normlex/ en/f?p=NORMLEXPUB:12100:0::NO::P12100_INSTRUMENT_ID:312326. Accessed 27 Mar 2016.

ILO. (2007). Guide to private employment agencies: Regulation, monitoring and enforcement. http://www.globalmigrationgroup.org/sites/default/files/uploads/UNCT_Corner/theme2/ labor-migration/guide_to_private_employment_agencies_wcms_118153.pdf. Accessed 29 Mar 2016.

Johns, M. (2013). Post-accession Polish migrants in Britain and Ireland: Challenges and obstacles to integration in the European Union. European Journal of Migration and Law, 15(1), 29-45.

Keter, V. (2007). Temporary and agency workers (Equal Treatment) Bill 27 2007-08. London: House of Commons Library. http://researchbriefings.files.parliament.uk/documents/RP08-17/ RP08-17.pdf. Accessed 20 Mar 2016.

Latviesi. (2015). Kā rìkoties, klūstot par negodīga darba devēja upuri [What to do if you have become a victim of a fraudulent employer]. https://www.latviesi.com/raksti/111441-ka-rikoties-klustot-par-negodiga-darba-deveja-upuri-stradajot-arzemes. Accessed 7 Apr 2016.

Luthra, R. R., Platt, L., \& Salamońska, J. (2014). Migrant diversity, migration motivations and early integration: the case of Poles in Germany, the Netherlands, London and Dublin. LEQS Paper, 74. http://www.lse.ac.uk/european-institute/research/leqs-discussion-paper-series/ papers. Accessed 28 Nov 2018.

MacKenzie, R., \& Forde, C. (2008). Migrant workers in low-skilled employment: Assessing the implications for human resource management. Paper presented at the annual meeting of the American Sociological Association Annual Meeting, Boston, MA. http://citation.allacademic. com/meta/p_mla_apa_research_citation/2/4/2/3/5/pages242354/p242354-9.php. Accessed 27 Mar 2016.

Mieriņa, I. (2016). Latvijas diasporas pieredze saskarsmē ar valsts institūcijām un darba devējiem arrpus Latvijas [Experience of Latvian diaspora interacting with the governmental institutions and employers abroad]. Rīga: LU Diasporas un migrācijas pētījumu centrs.

Migrant Workers Agency. (2007). Trade Union Congress. https://www.tuc.org.uk/internationalissues/migration/migrant-agency-workers-uk. Accessed 26 Mar 2016.

NVA. (2010). PTAC un NVA brīdina darba meklētājus par negodīgiem pakalpojumu sniedzējiem [Consumer Rights Protection Agency and State Employment Agency warns employment seekers about fraudulent employment services]. http://m.nva.gov.lv/LV/aktuala_informacija/ aktualitates/2084_ptac_un_nva_bridina_darba_mekletajus_par_negodigiem_pakalpojumu_ sniedzejiem.html. Accessed 5 Apr 2016.

NVA. (2015). Darbiekārtošanas pakalpojumi [Employment services]. http://www.nva.gov.lv/ index.php?cid=2\&mid=75. Accessed 25 Mar 2016. 
OSCE. (2006). Developing policies in countries of origin to protect migrant workers. Handbook on establishing effective labour migration policies of origin and destination countries. Vienna: Organisation for Security and Co-operation in Europe. http://www.osce.org/ eea/19248?download=true. Accessed 25 Mar 2016.

Pichler, F. (2011). Success on European labor markets: A cross-national comparison of attainment between immigrant and majority populations. International Migration Review, 45(4), 938-978.

Pijpers, R. (2010). International employment agencies and migrant flexiwork in an enlarged European Union. Journal of Ethnic and Migration Studies, 36(7), 1079-1097.

Pillinger, J. (2015). Running an effective migrant resource centre: A handbook for practitioners. Budapest: International Organisation for Migration. http://www.iom.hu/sites/default/files/ MRC.pdf. Accessed 27 Mar 2016.

Shubin, S., \& Dickey, H. (2013). Integration and mobility of Eastern European migrants in Scotland. Environment and Planning, 45(12), 2959-2979.

Smith, A. (1776). An inquiry into the nature and causes of the wealth of nations. http://geolib.com/ smith.adam/won1-08.html. Accessed 26 Mar 2016.

Söhn, J. (2013). Unequal welcome and unequal life chances: How the state shapes integration opportunities of immigrants. European Journal of Sociology, 54(02), 295-326.

Spreckelsen, T., \& Seeleib-Kaiser, M. (2016). Dimensions of labour market integration among young EU migrant citizens in the UK (Barnett Working Paper 16-01). Oxford: University of Oxford.

Summerville, W. (2004). The newcomers handbook. London: Centre for Economic and Social Inclusion.

van Liemt, G. (2013). Private employment agencies in the Netherlands, Spain and Sweden. International Labour Office, Sectoral Activities Department. Geneva: ILO.

Žabko, O. (2015). Darbiekārtošanās pakalpojumu sniedzēji kā migrācijas uz Norvēǵiju aǵgenti [Employment agents as migration to Norway promoters]. University of Latvia 73rd Conference. Riga: University of Latvia [Unpublished material].

Žabko, O., Aasland, A., \& Endresen, S. B. (2018). Facilitating labour migration from Latvia: Strategies of various categories of intermediaries. Journal of Ethnic and Migration Studies, 44(4), 575-591.

Open Access This chapter is licensed under the terms of the Creative Commons Attribution 4.0 International License (http://creativecommons.org/licenses/by/4.0/), which permits use, sharing, adaptation, distribution and reproduction in any medium or format, as long as you give appropriate credit to the original author(s) and the source, provide a link to the Creative Commons licence and indicate if changes were made.

The images or other third party material in this chapter are included in the chapter's Creative Commons licence, unless indicated otherwise in a credit line to the material. If material is not included in the chapter's Creative Commons licence and your intended use is not permitted by statutory regulation or exceeds the permitted use, you will need to obtain permission directly from the copyright holder.

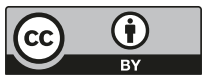

